\title{
PENGARUH KESADARAN LINGKUNGAN DAN SHARED VALUE CORPORATE SOCIAL RESPONSIBILITY TERHADAP NIAT BELI ULANG KFC INDONESIA
}

\author{
Liskia Maria Kristando ${ }^{1}$, Tias Andarini Indarwati ${ }^{2 *}$ \\ ${ }^{1}$ Jurusan Manajemen, Fakultas Ekonomi, Universitas Negeri Surabaya \\ Email: liskiakristando16080574082@mhs.ac.id \\ ${ }^{2}$ Jurusan Manajemen, Fakultas Ekonomi, Universitas Negeri Surabaya \\ Email: tiasindarwati@unesa.ac.id \\ *penulis korespondensi
}

Masuk : 28-09-2020y, revisi: 21-03-2021y, diterima untuk diterbitkan : 22-03-2021y

\begin{abstract}
ABSTRAK
Permasalahan lingkungan menjadi masalah yang sulit untuk dipecahkan, Indonesia merupakan negara dengan penyumbang sampah plastik di lautan terbesar kedua dunia. Sebagian besar sampah tersebut berasal dari sedotan plastik sekali pakai. Kondisi tersebut menyebabkan masyarakat khawatir sehingga beralih ke produk atau layanan yang perusahaannya bertanggung jawab terhadap lingkungan. KFC merupakan perusahaan restoran cepat saji yang melakukan kegiatan CSR dengan mengadakan gerakan \#nostrawmovement. Kegiatan ini bertujuan membangun kesadaran masyarakat terhadap bahaya sampah sedotan plastik sekali pakai. Penelitian ini adalah penelitian kuantitatif dengan desain penelitian kausalitas untuk menentukan pengaruh kesadaran lingkungan dan shared value corporate social responsibility terhadap niat beli ulang KFC (Studi pada KFC Indonesia). Teknik pengambilan sampel pada penelitian ini menggunakan judgmental sampling dengan ukuran sampel 200 responden yang merupakan konsumen KFC. Yaitu, Konsumen KFC yang pernah membeli minimal 2 kali. Hasil penelitian ini menunjukkan tidak ada pengaruh antara kesadaran lingkungan terhadap niat beli ulang KFC dan ada pengaruh signifikan positif antara shared value corporate social responsibility terhadap niat beli ulang KFC.
\end{abstract}

Kata Kunci: CSR, kesadaran lingkungan, restoran cepat saji, niat beli ulang

\begin{abstract}
Litter is an endless environmental issue that puzzled the mind, with that being said Indonesia is however still manage to put salt on the wound by contributing as second largest plasticbased garbage producer in the world. Most of those plastic outcast were plastic straw disposable. This situation naturally motivate environmental-caring consumer to turn their back to those of environmentally careless service provider and put their attention only for companies and businesses with a correct manner of responsibility to the environmental impact. Kentucky Fried Chicken (KFC) is a fast food restoran performing a Corporate Social Responsibility (CSR) program called \#nostrawmovement to educate the public about the menace of non-reusing plastic straw behavior, thus expected to encourage them to did not use plastic straw anymore.This work present a quantitative study with causality study by design to determine the relationship between environmental awareness alongside shared value corporate Social Responsibility (CSR) to repurchase intentions of KFC (a study of KFC Indonesia). The sampling method that deployed in this work is judgmental sampling with sample width of 200 respondent KFC's consumer. All the respondents at least buy the KFC's product twice. The result of this study showed that there is no connection between environmental awareness and buy back willingness of KFC's product, and also there is a significant positive leverage from Shared Value corporate Social Responsibility (CSR) to repurchase intention of KFC's product.
\end{abstract}

Keywords: CSR, environmental awareness, fastfood restoran, repurchase intention

\section{PENDAHULUAN}

\section{Latar Belakang}

Permasalahan lingkungan menjadi masalah yang rumit untuk dipecahkan dan sedotan plastik sekali pakai berada di peringkat kelima sebagai penyebabnya dikarenakan untuk dapat terurai dibutuhkan waktu yang lama. Material plastik yang tercacah di lautan menjadi mikro plastik sehingga dapat di konsumsi biota laut dan pada akhirnya di konsumsi oleh manusia 
(nationalgeographic.co.id, 2018). Terdapat sebesar 187,2 juta populasi pesisir di Indonesia yang setiap tahunnya menghasilkan 3,22 juta ton sampah plastik yang tidak terkelola dengan benar. Sekitar 0,48-1,29 juta ton dari sampah plastik tersebut diduga mencemari lautan (Jambeck et,al, 2015).

Meningkatnya kerusakan lingkungan membuat masyarakat menjadi lebih peka terhadap lingkungan sehingga menginginkan perusahaan lah yang bertanggung jawab terhadap keberlangsungan lingkungan (Xu, 2014). Untuk itu penting bagi perusahaan untuk menyediakan layanan yang dapat mengurangi rasa khawatir masyarakat dengan membangun perilaku bisnis bertanggung jawab terhadap lingkungan sehingga perusahaan tidak hanya mementingkan keuntungan bisnis semata tetapi juga memerhatikan keberlanjutan lingkungan sekitarnya. Ketika bisnis memenuhi harapan konsumen, mereka menjadi lebih berpengaruh dengan konsumen (Harun et al, 2018).

Corporate Social Responsibility (CSR) memprioritaskan pemenuhan kebutuhan konsumen yang ada kemudian di konvergensi dengan kesejahteraan sosial (Chun, 2014). Dengan melakukan kegiatan CSR perusahaan dapat menunjukan ke masyarakat bahwa perusahaan peduli akan keberlanjutan lingkungan. Menurut Choiri dan Nurhadi (2019) CSR merupakan sebuah komitmen perusahaan atau organisasi untuk terus menerus bertindak secara etis, beroperasi secara legal dan berkontribusi untuk meningkatkan kualitas komunitas lokal pada masyarakat secara lebih luas. Lima dimensi penting yang ada di CSR, yaitu dimensi lingkungan, sosial, ekonomi, stakeholder, voluntarines (Dahlsrud, 2008).

KFC bekerja sama dengan organisasi lingkungan Divers Clean Action membentuk suatu gerakan \#nostrawmovement yang merupakan bentuk tanggung jawab social (CSR) KFC terhadap lingkungan khususnya ekosistem laut. Cheng dan Huang (2018) membagi CSR dalam 2 kategori yaitu CSR tradisional dan Shared value corporate social responsibility, kali ini KFC melakukan kegiatan shared value corporate social responsibility dengan membangun kesadaran lingkungan dalam diri masyarakat. Tujuan \#nostrawmovement adalah untuk mengajak masyarakat untuk tidak lagi menggunakan sedotan plastik sekali pakai. Gerakan \#nostrawmovement memiliki beberapa kegiatan, yaitu kampanye anti sedotan plastik sekali pakai, KFC memberhentikan pemberian sedotan plastik sekali kepada konsumen, mengajak konsumen untuk memberikan sebagian uang kembaliannya untuk pemeliharaan laut Indonesia, serta edukasi tentang dampak dari penggunaan sedotan plastik sekali pakai dalam jangka panjang.

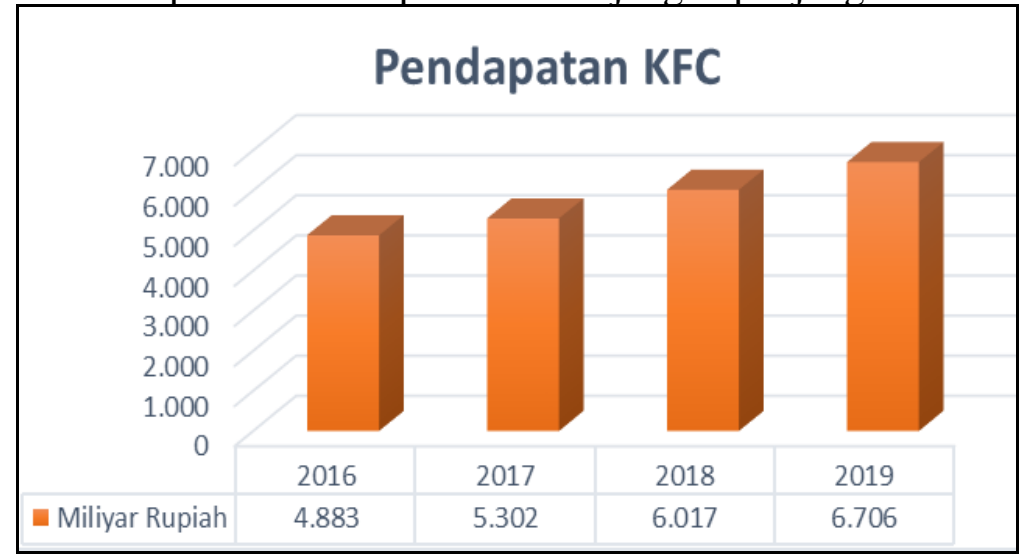

Gambar 1. Pendapatan KFC dari 2015-2019

Sumber : www.kfc.id, data di olah 
Berdasarkan gambar 1, diketahui bahwa Gerakan \#nostrawmovement ini mendapat sambutan baik konsumen, terbukti sejak kemunculan gerakan ini hingga Desember 2019 terjadi kenaikan pendapatan yang signifikan. Pada tahun 2016 saat belum membuat kegiatan \#nostrawmovement pendapatan KFC sebesar 4,883 miliar rupiah. Pada tahun 2017, KFC membuat gerakan \#nostrawmovement pendapatannya naik menjadi 5,302 miliar rupiah. Pada tahun 2018 terjadi kenaikan pendapatan lagi menjadi 6,017 miliar rupiah. Ketika seorang menyukai sesuatu hal maka akan timbul sikap positif. Sikap dapat membentuk niat dan perilaku seseorang (Ajzen, 1991).

Kini gerakan \#nostrawmovement telah menyebar luas di seluruh Indonesia dan mendapatkan perhatian lebih oleh masyarakat dan membuat pendapatan KFC meningkat menjadi 6706 miliar rupiah. Peningkatan pendapatan ini disebabkan oleh peningkatan pembelian. Hal ini selaras dengan pendapat Chen dan Chang (2012) yaitu konsumen cenderung membeli produk yang perusahaannya bertanggung jawab terhadap lingkungannya. Oleh karena itu dengan menciptakan kesadaran lingkungan, Konsumen akan menunjukkan dampak dari suatu produk atau layanan ramah lingkungan serta keinginan mereka untuk mengurangi efek melalui pilihan pembelian mereka (Karatu, 2015). Martana (2018) menemukan pengalaman yang baik ketika menggunakan produk atau layanan yang peduli terhadap lingkungan dapat meningkatkan niat beli ulang konsumen.Tetapi hal yang berbeda di ungkapkan Huang Liu (2013), kesadaran lingkungan tidak berpengaruh terhadap niat pembelian suatu produk ramah lingkungan. Mishal et al. (2017) juga menyebutkan bahwa peningkatan kesadaran lingkungan tidak berbanding lurus dengan peningkatan niat beli konsumen.

Dalam melakukan suatu kegiatan pemasaran, kebutuhan konsumen harus juga diperhatikan. Konsumen telah menjadi kekuatan utama yang harus diperhitungkan untuk mencapai tujuan perlindungan lingkungan dan pembangunan berkelanjutan (Sharma, Bansal 2013). Dengan di adakannya gerakan \#nostrawmovement ini KFC menunjukan kepada masyarakat bahwa KFC peduli terhadap keberlanjutan lingkungan. CSR dapat meningkatkan hubungan dengan pelanggan dan kepuasan pelanggan (Chun, 2014; Chen \& Huang 2018) membuktikan bahwa shared value corporate social responsibility berpengaruh positif terhadap evaluasi produk dan niat beli. Jose (2015), menyatakan bahwa kegiatan CSR yang sesuai dengan target pasarnya akan berpengaruh positif terhadap niat beli ulang. Sementara penelitian Acabou (2019), menyatakan bahwa walaupun sensitivitas responden terhadap isu sosial dan lingkungan tetapi tidak memengaruhi niat beli suatu produk. Hasil penelitian dari Choiri dan Nurhadi (2019) menyatakan bahwa CSR tidak mempengaruhi niat beli konsumen. Harun et al. (2018), menyatakan bahwa CSR saja tidak cukup untuk membentuk Niat Beli Ulang.

Berdasarkan uraian dan kesenjangan penelitian terdahulu yang menyebabkan penelitian ini dilakukan karena adanya research gap seperti yang telah dipaparkan sebelumnya, penelitian ini bertujuan untuk mengetahui Pengaruh Kesadaran Lingkungan dan Shared Value Corporate Social Responsibility terhadap Niat Beli Ulang. Oleh sebab itu, diharapkan penelitian ini dapat memberikan kontribusi terhadap pelaku usaha di Indonesia dalam pengembangan dan pengelolaan usaha dengan menggunakan CSR sebagai salah satu media pemasaran sehingga dapat meningkatkan niat beli ulang konsumen.

\section{Rumusan Masalah}

1. Apakah Kesadaran Lingkungan berpengaruh terhadap niat beli ulang di Kentucky Fried Chicken (KFC)? 
2. Apakah shared value corporate social responsibility berpengaruh terhadap niat beli ulang Konsumen di Kentucky Fried Chicken (KFC)?

\section{METODE PENELITIAN}

Penelitian ini termasuk ke dalam penelitian jenis kuantitatif dengan model kausalitas. Teknik pengambilan sampel yang digunakan oleh peneliti adalah nonprobability sampling dengan menggunakan judgmental sampling. Data yang digunakan dalam penelitian ini adalah data primer yang di peroleh dari angket yang disebarkan, data sekunder diperoleh dari buku literatur, jurnal, artikel ilmiah maupun berita. Variabel bebas yang terdapat pada penelitian ini adalah kesadaran lingkungan dan shared value corporate social responsibility. Sedangkan variabel terikat dalam penelitian ini adalah niat beli ulang. Populasi yang menjadi sasaran adalah konsumen KFC dengan kriteria berusia antara 19-50 tahun, pernah melakukan transaksi sebanyak 2 kali dan berdomisili di pulau Jawa. Jumlah sampel penelitian ini adalah 200 orang. Teknik pengumpulan data yang digunakan adalah angket kuesioner yang didistribusikan secara online melalui Google Form yang disebar kepada pengguna twitter dan instagram yang mengikuti media sosial KFC.

Pengujian sampel di lakukan pada beberapa responden awal kemudian dilakukan uji validitas dan reliabilitas terhadap insturemen penelitian yang akan digunakan. Setelah lolos uji ini, maka selanjutnya akan disebar untuk memperoleh 200 responden uji asumsi klasik dan memenuhi model regresi linier berganda. Data yang terkumpul dianalisis dengan regresi linier berganda menggunakan software SPSS 23 dengan menggunakan uji asumsi klasik yaitu uji normalitas, uji multikolinieritas dan uji heterokedastisitas. Selanjutnya, data akan diproses dengan uji hipotesis dengan menggunakan Uji t, uji koefisien determinasi dan uji f.

\section{HASIL DAN PEMBAHASAN}

\section{Karakteristik Responden}

Hasil penyebaran angket secara online kepada pengguna twitter dan instagram yang mengikuti media sosial KFC, 60\% responden berdomisili di Jawa Timur dengan 177 responden berusia nya 19-24 tahun. Di rentang usia tersebut mayoritas responden pendidikan terakhir SMA dengan pengeluaran per bulan kurang dari Rp.1.000.000. Frekuensi kunjungan responden per-bulannya sebanyak 1-2 kali dan mengetahui informasi mengenai KFC melalui media sosial.

Tabel 1. Karakteristik Responden

Sumber tabel : diolah peneliti

\begin{tabular}{llll}
\hline \multicolumn{2}{c}{ Karakteristik Responden } & Jumlah & Presentase \\
\hline Domisili & Jawa Timur & 120 & $60 \%$ \\
\hline & Jawa Tengah & 14 & $7 \%$ \\
\hline & D I Y & 20 & $10 \%$ \\
\hline Jawa Barat & 17 & $8,50 \%$ \\
\hline Prov Banten & 17 & $8,50 \%$ \\
\hline Usia & DKI Jakarta & 12 & $6 \%$ \\
\hline & $19-24$ tahun & 177 & $88,50 \%$ \\
\hline 25-30 tahun & 12 & $6 \%$ \\
\hline & $31-35$ tahun & 6 & $3 \%$ \\
\hline Jenis Kelamin & 36-40 tahun & 1 & $0,50 \%$ \\
\hline & $41-45$ tahun & 3 & $1,50 \%$ \\
\hline Pendidikan & Lak-50 tahun & 1 & $0,5 \%$ \\
\hline & Perempuan & 86 & $43 \%$ \\
\hline
\end{tabular}




\begin{tabular}{|c|c|c|c|}
\hline \multicolumn{4}{|l|}{ Terakhir } \\
\hline & Diploma & 19 & $9,50 \%$ \\
\hline & $\mathrm{S} 1$ & 49 & $24,50 \%$ \\
\hline & $\mathrm{S} 2$ & 3 & $1,50 \%$ \\
\hline \multirow[t]{6}{*}{ Pekerjaan } & Pelajar/Mahasiswa & 146 & $73 \%$ \\
\hline & Pegawai Swasta & 33 & $16,50 \%$ \\
\hline & $\begin{array}{l}\text { Pegawai Negeri } \\
\text { Sipil }\end{array}$ & 6 & $3 \%$ \\
\hline & Wiraswasta & 6 & $3 \%$ \\
\hline & $\begin{array}{l}\text { Ibu Rumah } \\
\text { Tangga }\end{array}$ & 4 & $2 \%$ \\
\hline & Lainnya & 5 & $2,50 \%$ \\
\hline \multirow[t]{5}{*}{$\begin{array}{l}\text { Pengeluaran per } \\
\text { bulan }\end{array}$} & < Rp. 1.000 .000 & 93 & $46,50 \%$ \\
\hline & $\begin{array}{l}\text { Rp. } 1.000 .000- \\
\text { Rp. } 3.000 .000\end{array}$ & 86 & $43 \%$ \\
\hline & $\begin{array}{l}\text { Rp. } 3.000 .000- \\
\text { Rp. } 5.000 .000\end{array}$ & 11 & $5,50 \%$ \\
\hline & $\begin{array}{l}\text { Rp. } 5.000 .000- \\
\text { Rp. } 7.000 .000\end{array}$ & 8 & $4 \%$ \\
\hline & > Rp. 7.000.000 & 2 & $1 \%$ \\
\hline \multirow{2}{*}{$\begin{array}{l}\text { Frekuensi } \\
\text { kunjungan KFC } \\
\text { dalam sebulan }\end{array}$} & 1-2 Kali & 151 & $75,5 \%$ \\
\hline & $>2$ Kali & 49 & $24,5 \%$ \\
\hline \multirow{4}{*}{$\begin{array}{l}\text { Sumber Informasi } \\
\text { mengenai KFC }\end{array}$} & Teman & 57 & $28,5 \%$ \\
\hline & Keluarga & 57 & $28,5 \%$ \\
\hline & Media Sosial & 76 & $38 \%$ \\
\hline & Lainnya & 10 & $5 \%$ \\
\hline
\end{tabular}

\section{Hasil Uji Asumsi Klasik}

Sebelum melakukan uji regresi untuk memperoleh hasil maka dilakukan uji asumsi klasik untuk mengetahui kepastian ketepatan persamaan regresi. Hasil ini dijelaskan sebagai berikut: 1) Hasil uji normalitas data menggunakan One-Sample Kolmogorov-Smirnov Test diperoleh hasil nilai signifikansi Asymp. Sig. (2-tailed) sebesar 0,059 lebih besar dari 0,05. Maka sesuai dasar pengambilan keputusan dalam uji normalitas dapat disimpulkan bahwa data tersebut berdistribusi normal. 2) Hasil Uji Multikolinieritas diperoleh nilai VIF dari variabel kesadaran lingkungan yaitu $2,840 \leq 10$. Dan nilai VIF dari variabel shared value csr yaitu 2,840 $\leq 10$. Artinya tidak terjadi multikolonieritas antar variabel independent. 3) Nilai sig. (2-tailed) pada X1 sebesar 0,414 atau >0,05 dan pada X2 sebesar 0,168 atau >0,05.

\section{Hasil Uji Regresi Linier Berganda}

Setelah memperoleh hasil uji asumsi klasik yang sesuai maka selanjutnya dilakukan uji regresi linier berganda. Uji regresi linier berganda menggunakan software SPSS 23 memperoleh hasil sebagai berikut. 
Tabel 2. Hasil Uji Regresi Linier Berganda

Sumber tabel : Output SPSS 23

\begin{tabular}{|c|c|c|c|c|c|c|}
\hline \multirow{2}{*}{ Model } & & \multicolumn{3}{|c|}{ Unstandardized Coefficients } & \multirow{2}{*}{$\mathrm{t}$} & \multirow{2}{*}{ Sig. } \\
\hline & & B & & Std. Error & & \\
\hline \multirow[t]{3}{*}{1} & (Constant) & & 6.333 & 1.828 & 3.464 & .001 \\
\hline & $\begin{array}{l}\text { Kesadaran } \\
\text { Lingkungan }\end{array}$ & & .150 & .081 & 1.860 & .064 \\
\hline & Shared Value CSR & & .227 & .048 & 4.720 & .000 \\
\hline
\end{tabular}

Dari tabel tersebut diperoleh persamaan regresi linear berganda sebagai berikut:

\section{$\mathrm{Y}=6,333+0.250 \mathrm{X} 1+0.227 \mathrm{X} 2$}

Sehingga dari hasil tersebut dapat diinterpretasikan bahwa Nilai konstanta pada persamaan regresi linear berganda sebesar 6,333 merupakan nilai niat beli ulang apabila tidak menggunakan variabel kesadaran lingkungan dan shared value corporate social responsibility yang artinya niat beli ulang KFC tetap terjadi. Nilai positif menunjukkan bahwa niat beli ulang KFC akan tetap terbentuk meski tidak mengetahui kesadaran lingkungan dan shared value corporate social responsibility. Nilai koefisien kesadaran lingkungan sebesar 0,150 menunjukan apabila nilai kesadaran lingkungan meningkat sebesar 1 satuan, maka nilai niat beli ulang akan mengalami kenaikan sebesar 0,210 dan Shared Value CSR (X2) memiliki nilai 0,227, berarti bahwa apabila nilai Shared Value CSR meningkat sebesar 1 satuan, maka nilai niat beli ulang akan mengalami kenaikan sebesar 0,227.

\section{Hasil Uji Kelayakan Model}

Dari hasil uji kelayakan model dapat dijelaskan bahwa nilai kontribusi atau nilai Adjusted $\mathrm{R}^{2}$ untuk variabel independen yaitu kesadaran lingkungan (X1) dan Shared Value CSR (X2) terhadap variabel dependen yaitu Niat beli ulang KFC (Y) sebesar 0,297 atau sebesar 30\%. Artinya kesadaran lingkungan dan Shared Value CSR memiliki proporsi pengaruh terhadap keputusan pembelian sebesar 30\% dan sisanya 70\% dipengaruhi oleh variabel lain yang tidak termasuk dalam penelitian.

\section{Hasil Uji Hipotesis (Uji t)}

Berdasarkan tabel 2 hasil pengujian hipotesis variabel kesasaran lingkungan (X1)dapat diketahui nilai t-hitung sebesar 0,150 dengan signifikansi 0,64 dimana nilai $\alpha$ tersebut memiliki nilai lebih besar dari 0,05. Nilai tersebut menjelaskan bahwa kesadaran lingkungan tidak berpengaruh terhadap niat beli ulang KFC. Selanjutnya untuk untuk variabel shared value CSR (X2) memperoleh nilai t-hitung sebesar 0,227 dengan signifikansi 0,000 dimana nilai $\alpha$ tersebut memiliki nilai lebih kecil drai 0,05 . atau $5 \%$, maka $\mathrm{H}_{0}$ ditolak dan $\mathrm{H} 1$ diterima. Sehingga dapat dikatakan bahwa terdapat pengaruh positif antara shared value CSR terhadap niat beli ulang KFC. 


\section{Hasil Uji Hipotesis Uji f}

Uji Signifikansi Simultan (Uji-F) dalam penelitian ini dapat dilihat pada tabel berikut ini:

Tabel 3. Hasil Uji Hipotesis Uji F

Sumber tabel : Output SPSS 23

\begin{tabular}{llll}
\hline Model & & F & Sig. \\
\hline 1 & $\begin{array}{l}\text { Regression } \\
\text { Residual }\end{array}$ & 43.055 & $.000^{\mathrm{a}}$ \\
\cline { 2 - 4 } & Total & & \\
\hline
\end{tabular}

Berdasarkan tabel 3, di dapat $\mathrm{F}$ hitung sebesar 43.055 dengan probabilitas sebesar 0,000 yang nilainya dibawah 0,05 . Hal ini menunjukkan bahwa semua variabel independen yatu kesadaran lingkungan dan Shared value CSR berpengaruh signifikan secara simultan (bersama-sama) terhadap Niat Beli Ulang KFC. Dengan demikian, hipotesis ketiga diterima.

\section{PEMBAHASAN}

\section{Pengaruh Kesadaran Lingkungan terhadap Niat Beli Ulang}

Permasalahan lingkungan menjadi masalah yang rumit untuk dipecahkan, dan peningkatan kerusakan lingkungan membuat masyarakat menjadi lebih peka terhadap lingkunganya. Kesadaran lingkungan adalah konstruk multidimensi yang diketahui memengaruhi pengetahuan, sikap, perilaku, niat, dan tindakan seseorang (Mishal et al. 2017). Semakin tinggi tingkat kesadaran lingkungan yang di miliki seseorang semakin tinggi juga keinginan mereka membeli produk atau layanan yang ramah lingkungan (Akehurst et al., 2012). Kesadaran Lingkungan membuat konsumen menjadi peka terhadap sejauh mana menahan diri untuk membeli produk yang berbahaya bagi lingkungan. Niat beli ulang adalah kegiatan pembelian yang dilakukan konsumen setelah mereka melakukan pembelian pertama kali dari produk maupun jasa yang dilakukan secara berulang pada jangka waktu tertentu dan secara aktif menyukai dan mempunyai sikap positif terhadap suatu produk barang/jasa, didasarkan pada pengalaman yang telah dilakukan dimasa lampau (Martana, 2018).

Hasil penelitian pada minuman kemasan oleh Martana (2018) yang menyatakan bahwa kesadaran lingkungan berpengaruh positif dan signifikan terhadap niat beli ulang. Berbeda dengan hasil penelitian Huang Liu (2013), Mishal et al. (2017) yang menyatakan bahwa kesadaran lingkungan tidak berpengaruh signifikan terhadap niat beli konsumen. Kesadaran lingkungan pada penelitian ini menggunakan empat indicator yaitu pengetahuan lingkungan, sikap positif terhadap lingkungan, tindakan lingkungan dan tindakan dalam membeli produk. Item pernyataan yang memiliki nilai tertinggi pada variabel ini adalah "responden mengetahui bahwa limbah sedotan plastik sekali pakai merupakan salah satu faktor pencemaran lingkungan". Hasil penelitian ini menyatakan bahwa kesadaran lingkungan tidak berpengaruh signifikan terhadap niat beli ulang. mendukung penelitian dari Huang Liu (2013) dan Mishal et al. (2017).

Konsumen KFC di Indonesia yang menjadi responden pada penelitian ini memiliki karekteristik pelajar SMA hingga mahasiswa baik laki-laki maupun perempuan dengan pengeluaran per bulannya kurang dari Rp 1.000.000,00 dan melakukan kunjungan 1-2 kali per bulan. Responden terbesar berasal dari Jawa Timur dan mengetahui informasi tentang KFC dari social Media. Hal ini menunjukkan bahwa konsumen KFC kebanyakan adalah kalangan muda yang mengetahui bahwa \#nostrawmovement merupakan aksi peduli KFC dengan menjadikan produknya lebih ramah lingkungan dengan tidak memberikan sedotan plastik dalam rangka mengurangi salah satu factor pencemaran lingkungan. 
Bang (2000) menyatakan bahwa konsumen yang memiliki keadaran lingkungan yang tinggi akan bersedia membayar lebih untuk renewable energy daripada yang rendah kesadarannya terhadap lingkungan Hal ini sesuai dengan data Jejak Pendapat Kompas yang menyatakan bahwa hanya 6.3\% responden di Jabotabek yang menggunakan reuseable straw dari bambu ataupun dari besi. Responden yang merupakan pelanggan KFC dipenelitian ini merupakan generasi milenial yang masih rendah kesadaran lingkungannya, mereka baru pada tahap sekedar mengetahui dan belum mengimplementasikannya. Konsumen KFC yang kebanyakan anak muda dengan pengeluaran di bawah Rp 2.000.000,00 yang memilih tempat makan tersebut dengan melihat informasi dari social media merupakan segmen pasar yang sensitive price dimana mereka memilih tempat makan sesuai dengan kondisi finansial mereka. Mereka memiliki niat membeli produk KFC bukan karena produk itu lebih ramah lingkungan karena \#nostrawmovement akan tetapi karena masih sesuai dengan pengeluaran mereka Responden memilih KFC bukan karena kesadaran lingkungan akan tetapi niat beli mereka lebih dipengaruhi oleh faktor lain.

\section{Pengaruh Shared Value CSR (X2) terhadap Niat Beli Ulang (Y)}

Suatu program yang membuat peningkatan nyata untuk kesejahteraan social akan memberikan citra yang unik dan perasaan positif Kotler \& Lee (2005). Pride et al (2015), menyatakan bahwa kegiatan usaha yang berdampak bagi masyarakat berpengaruh pada proses pengambilan keputusan konsumen. Shared-value CSR merupakan kegiatan yang melibatkan elemen bisnis mulai dari produsen, konsumen, stake holder untuk menciptakan suatu program bisnis yang membentuk nilai bagi masyarakat. Penelitian oleh Chen dan Huang (2018) membuktikan bahwa shared value corporate social responsibility berpengaruh positif terhadap evaluasi produk dan niat beli. Jose (2015), menyatakan bahwa kegiatan CSR yang sesuai dengan target pasarnya akan berpengaruh positif terhadap niat beli ulang. Sementara penelitian dari Harun et al. (2018) dan Acabou (2019), yang menujukan hasil tidak signifikan antara CSR dengan niat beli konsumen.

Hasil penelitian ini menunjukkan bahwa variabel shared value corporate social respondibility memiliki pengaruh signifikan terhadap niat beli ulang. Pengaruh dari variabel shared value corporate social respondibility terhadap niat beli ulang memiliki nilai yang positif dan menunjukkan hubungan yang searah, yang artinya apabila KFC melakukan kegiatan shared value corporate social respondibility akan meningkatkan niat beli kembali konsumen pada produk-produk KFC. Variabel shared value corporate social responsibility dalam penelitian ini diukur menggunakan empat indikator yaitu citra perusahaan, citra kemampuan perusahaan, kepercayaan terhadap perusahaan, evaluasi perusahaan. Pada keempat indikator tersebut, jawaban dari responden memiliki nilai rata-rata tertinggi adalah "Gerakan \#nostrawmovement menunjukan bahwa KFC sangat memperhatikan masalah lingkungan yang sedang terjadi”.

Konsumen KFC dalam penelitian ini seperti yang digambarkan di atas merupakan kelompok pelajar baik laki-laki maupun perempuan yang memiliki pengeluaran di bawah Rp 2.000.000,00 yang berkunjung sebanyak 1-2 kali per bulan. tentu saja mengetahui bahwa KFC melakukan \#nostrawmovement yang merupakan kegiatan shared value CSR. Hasil jaswaban responden akan gerakan \#nostrawmovement menunjukan bahwa KFC sangat memperhatikan masalah lingkungan yang sedang terjadi saat ini, menunjukkan bagaimana share value CSR yang dilakukan oleh KFC diterima oleh kaum muda. Selaras dengan penelitian Czap (2010), menyatakan bahwa ketika melakukan kegiatan berkaitan dengan lingkungan harus diperhatikan sub kelompok. Kelompok muda merupakan kelompok dengan penghasilan rendah yang mana mereka lebih bersedia melakukan aktivitas dalam gerakan menjaga lingkungan daripada harus mendonasikan uangnya. Nilai-nilai yang dibagikan perusahaan akan gerakan \#nostrawmovement 
ini merupakan nilai-nilai aktivitas dalam menjaga lingkungan dengan tidak menggunakan sedotan plastik.

\section{Pengaruh Kesadaran Lingkungan dan Shared Value CSR (X2) secara simultan terhadap Niat Beli Ulang (Y)}

Konsumen menjadi sadar akan lingkungan sehingga meminta perusahaan yang bertanggung jawab terhadap lingkungan. Kesadaran lingkungan mengacu pada faktor psikologis yang menentukan kecenderungan individu terhadap perilaku proenvironmental (Zelezny \& Schultz, 2000). Ketika perusahaan melakukan aksi nyata untuk lingkungan maka perusahaan tersebut menjadi lebih berpengaruh terhadap konsumen (Harun et al, 2018).

Hasil penelitian ini maka menunjukkan bahwa secara simultan variabel kesadaran lingkungan dan shared value corporate social respondibility berpengaruh signifikan terhadap niat beli ulang. Pengaruh dari variabel kesadaran lingkungan dan shared value corporate social respondibility terhadap niat beli ulang memiliki nilai yang positif dan menunjukkan hubungan yang searah, yang artinya apabila masyarakat sadar akan kondisi lingkungan dan di sertai oleh tindakan perusahaan yang bertanggung jawab terhadap lingkungan maka dapat menciptakan niat beli ulang pada produk yang lebih ramah lingkungan.

\section{KESIMPULAN DAN SARAN}

Gerakan \#nostrawmovement merupakan gerakan kesadaran lingkungan yang merupakan shared value corporate social respondibility yang dilakukan KFC dengan pendekatan tidak memberikan sedotan plastik pada produknya. Sedotan plastik merupakan material plastik yang tercacah di lautan menjadi mikro plastik sehingga dapat di konsumsi biota laut dan pada akhirnya di konsumsi oleh manusia. Strategi \#nostrawmovement merupakan strategi yang tepat dalam meningkatkan kesadaran kaum muda untuk lebih sadar akan lingkungan. Hasil penelitian ini menunjukkan bahwa kaum muda baru sebatas mengetahui bahwa limbah sedotan plastik sekali pakai merupakan salah satu factor pencemaran lingkungan. Kaum muda tidak bersedia untuk mengeluarkan biaya lebih besar dalam niat membeli produk KFC akan tetapi tidak keberatan apabila KFC tidak menyediakan sedotan plastik untuk pelanggannya. Terbukti responden masih rutin untuk berminat membeli produk KFC 1-2 kali per bulan. Selain itu kegiatan ini merupakan shared value corporate social respondibility KFC baik kepada masyarakat maupun lingkungannya. Strategi \#nostrawmovement menurut penulis merupakan strategi yang jitu bagi KFC, dilihat dari sisi operasional maka aktivitas ini membuat KFC dapat mengurangi biaya yang cukup besar dalam penyediaan sedotan plastik. Selain itu di sisi pemasaran, seperti yang kita ketahui bahwa gerakan \#nostrawmovement telah menjadikan kaum muda melakukan gerakan cinta lingkungan dan KFC mengajarkan nilai-nilai baik terutama terkait pengurangan sedotan plastik sekali pakai dalam rangka mengurangi salah satu factor pencemaran lingkungan. Meskipun prosentasi kesadaran lingkungan kaum muda masih belum ditunjukkan dalam niat membeli kembali produk KFC, akan tetapi dari gerakan tersebut seperti yang tertuang pada twitter admin KFC terdapat beberapa pernyataan pelanggan yang menyatakan menjadi lebih tenang membeli produk KFC karena perusahaan memikirkan produknya untuk menjadi produk yang ramah lingkungan.

Dapat disimpulkan bahwa gerakan \#nostrawmovement ini sangat efektif dan efisien, bagaimana tidak dengan gerakan ini biaya operasional sedotan plastik terpangkas akan tetapi membawa citra baik bagi KFC sebagai perusahaan yang menanamkan nilai-nilai cinta lingkungan kepada kaum muda dengan memulai dari sesuatu yang kecil yaitu tidak menggunakan sedotan plastik. 
Penelitian ini tentunya memiliki keterbatasan diantaranya 1) Referensi literatur atau penelitian terdahulu mengenai kesadaran lingkungan dan shared value corporate social respondibility masih terbatas, 2) Terbatasnya informasi yang didapatkan karena pertanyaan pada angket bersifat tertutup, 3) Penyebaran angket dalam penelitian ini hanya dilakukan secara online. Sehingga dari hal tersebut disarankan untuk peneliti selanjutnya diharapkan melakukan penelitian mengenai kesadaran lingkungan dan shared value corporate social respondibility terhadap niat beli ulang, sehingga dapat menjadi referensi untuk penelitian mengenai kesadaran lingkungan dan shared value corporate social respondibility terhadap niat beli ulang. Selain itu dapat juga menggunakan angket terbuka pada item pertanyaan yang membutuhkan informasi luas. Dapat juga menggunakan angket online dan offline untuk mendapatkan informasi yang luas. Dan juga sebaiknya menambahkan variabel-variabel lain diluar variabel yang diteliti, mengingat kemampuan variabel independen menjelaskan keputusan pembelian masih sebesar $31 \%$ dan masih dapat ditingkatkan.

\section{Ucapan Terima Kasih}

Puji syukur kepada Tuhan Yang Maha Esa, karena kehendak dan karuniaNya peneliti dapat menyelesaikan artikel ini. Artikel ini tidak dapat diselesaikan tanpa bantuan dan bimbingan dari orang - orang yang telah mendukung penulis. Maka dari itu penulis ingin meyampaikan rasa terima kasih kepada Ibu Tias Andarini Indarwati, S.E., M.M., selaku dosen Pembimbing, ibu Dr. Sri Setyo Iriani, S.E., M.Si., selaku dosen penguji I, Ibu Monika Tiarawati, S.E., M.M., selaku penguji II dan bapak Dr. Ulil Hartono, S.E., M.Si., selaku Ketua Jurusan Manajemen UNESA. Terima kasih kepada orang tua dan teman-teman semua yang sudah selalu mendukung dan membantu proses penyelesaian artikel ini.

\section{REFERENSI}

Achabou, M. A. (2020). The effect of perceived CSR effort on consumer brand preference in the clothing and footwear sector. In European Business Review (Vol. 32, Issue 2). https://doi.org/10.1108/EBR-11-2018-0198

Akehurst, G., Afonso, C., \& Gonçalves, H. M. (2012). Re-examining green purchase behaviour and the green consumer profile: New evidences. Management Decision, 50(5), 972-988. https://doi.org/10.1108/00251741211227726

Alicia,Nesa. (2018). Sampah Sedotan Plastik Mengancam Bumi, Berbagai Pihak Mulai Berbenah. national geographic.co.id. Diakses dari https://nationalgeographic.grid.id/read/13941728/sampah-sedotan-plastik-mengancambumi-berbagai-pihak-mulai-berbenah

Chen, X., \& Huang, R. (2018). The impact of diverse corporate social responsibility practices on consumer product evaluations. Journal of Product and Brand Management, 27(6), 701715. https://doi.org/10.1108/JPBM-01-2017-1390

Chen, Y. S., \& Chang, C. H. (2012). Enhance green purchase intentions: The roles of green perceived value, green perceived risk, and green trust. Management Decision, 50(3), 502520. https://doi.org/10.1108/00251741211216250

Dahlsrud, A. (2008). How corporate social responsibility is defined: An analysis of 37 definitions. Corporate Social Responsibility and Environmental Management, 15(1), 1-13. https://doi.org/10.1002/csr.132

Devi Juwaheer, T., Pudaruth, S., \& Monique Emmanuelle Noyaux, M. (2012). Analysing the impact of green marketing strategies on consumer purchasing patterns in Mauritius. World Journal of Entrepreneurship, Management and Sustainable Development, 8(1), 36-59. https://doi.org/10.1108/20425961211221615 
Fojt, M. (1994). International Journal of Bank Marketing. International Journal of Bank Marketing, 12(7), 1-32. https://doi.org/10.1108/02652323199400002

Harun, A., Prybutok, G., \& Prybutok, V. (2018). Do the millennials in the USA care about the fastfood industry's involvement in corporate social responsibility? Young Consumers, 19(4), 358-381. https://doi.org/10.1108/YC-02-2018-00776

Hoegh-Guldberg, O., Cai, R., Poloczanska, E., Brewer, P., Sundby, S., Hilmi, K., Fabry, V., \& Jung, S. (2015). Plastic waste inputs from land into the ocean. Science, September 2014, 1655-1734. https://doi.org/10.1017/CBO9781107415386.010

Karatu, V. M. H., \& Mat, N. K. N. (2015). Predictors of Green Purchase Intention in Nigeria : The Mediating Role of Environmental Consciousness, 5(2), 291-302. https://doi.org/10.5923/c.economics.201501.38of Green Purchase Intention. American Journal of Economics, 5(2), 291-302. https://doi.org/10.5923/c.economics.201501.38

Kfcku.com. 2020. Financial Report. Diakses dari https://kfcku.com/financial-report

Kotler, P., \& Keller, K. L. (2009). Manajemen Pemasaran Jilid 1 (Edisi 13). Jakarta: Erlangga.

Krisna, Albertus. (2019). "Diet” Plastik Warga Kota. kompas.id. Diakses dari https://www.kompas.id.diet-plastik-warga-kota

Liu, H., Sato, H., Morikawa, T., Studies, E., Area, C., To, I., Protocol, K., \& Stra, G. V. (2013). Influences of Environmental Consciousness and Attitudes to Transportation on Electric Vehicle Purchase Intentions. 9(4), 430-446.

Martana, I. M. Y., \& Ardani, I. G. A. K. S. (2018). Peran Sikap Dalam Memediasi Pengaruh Kesadaran Lingkungan Terhadap Niat Beli Ulang Produk Minuman Kemasan Hijau. E$\begin{array}{llll}\text { Jurnal Manajemen Universitas } & \end{array}$ https://doi.org/10.24843/ejmunud.2018.v07.i10.p10

Mishal, A., Dubey, R., Gupta, O. K., \& Luo, Z. (2017). Dynamics of environmental consciousness and green purchase behaviour: an empirical study. International Journal of Climate Change Strategies and Management, 9(5), 682-706. https://doi.org/10.1108/IJCCSM-11-2016-0168

Muid Al Choiri, M. A., \& Nurhadi, M. (2019). The Effect of Corporate Social Responsibility (CSR) on Purchase Intention Through Brand Images as a Variable Mediation in Telkom Product in Surabaya. Journal of Business \& Banking, 8(2), 337. https://doi.org/10.14414/jbb.v8i2.1652

Neolaka, Amos. 2008. Kesadaran Lingkungan. Jakarta : PT Rineka Cipta

None, I., \& Kumar Datta, S. (2011). Pro-environmental Concern Influencing Green Buying: A Study on Indian Consumers. International Journal of Business and Management, 6(6), 124-133. https://doi.org/10.5539/ijbm.v6n6p124

Schlegelmilch, B. B., Bohlen, G. M., \& Diamantopoulos, A. (1996). The link between green purchasing decisions and measures of environmental consciousness. European Journal of Marketing, 30(5), 35-55. https://doi.org/10.1108/03090569610118740

Sharma, K., \& Bansal, M. (2013). Environmental consciousness, its antecedents and behavioural outcomes. Journal of Indian Business Research, 5(3), 198-214. https://doi.org/10.1108/JIBR-10-2012-0080

$\mathrm{Xu}, \mathrm{Y}$. (2014). Understanding CSR from the perspective of Chinese diners: The case of McDonald's. International Journal of Contemporary Hospitality Management, 26(6), 1002-1020. https://doi.org/10.1108/IJCHM-01-2013-0051

Zelezny, L.C. and Schultz, P. (2000). "Psychology of promoting environmentalism : promoting environmentalism”. Journal of Social Issues, 56 (3), 365- 371.

https://doi.org/10.1111/0022-4537.00172. 